\title{
Description and biological features of a new species of Anagrus Haliday (Hymenoptera, Mymaridae)
}

\author{
F. Nugnes, G. Viggiani \\ Laboratorio di Lotta Biologica, Dipartimento di Agraria, Università di Napoli Federico II, Portici, Italy
}

\begin{abstract}
Anagrus lindberginae sp. n. (Hymenoptera: Mymaridae), an egg parasitoid of the leafhopper Lindbergina aurovittata (Homoptera: Cicadellidae), is described from Italy. It is included in the atomus group of Anagrus Haliday and compared with the allied known taxa. The parasitoid's life cycle is characterized by a long larval diapause from spring to fall, which allows for synchronization with its leafhopper host; other biological traits of $A$. lindberginae on the evergreen plant Quercus ilex are discussed.
\end{abstract}

Correspondence: Gennaro Viggiani, Laboratorio di Lotta Biologica, Dipartimento di Agraria, Università degli Studi di Napoli Federico II, Via Università 133 , Portici (NA), Italy

E-mail: genviggi@unina.it

Key words: Anagrus lindberginae, Anagrus atomus, Anagrus ustulatus, Lindbergina aurovittata, egg parasitoid, biology.

Contributions: FN contributed for the morpho-biological characterization of the new species; GV is the author of some taxonomic aspects of the paper and of the morphometric analysis of the Anagrus species involved.

Acknowledgments: the authors are grateful to Dr. Umberto Bernardo, CNR Istituto per la Protezione delle Piante, Unità Organizzativa di Supporto, Portici and to Dr. Serguei Triapitsyn, University of California, Riverside, USA, for their suggestions and comments on the manuscript.

To meet the requirements by the International Code of Zoological Nomenclature (ICZN), this article was registered at ZooBank (20 February 2014) under the ZooBank Life Science Identifier (LSID): CCE1A02C-5D524A25-A0B0-CCDF-74C5-66E2

Received for publication: 13 November 2013.

Revision received: 19 February 2014.

Accepted for publication: 4 March 2014.

Published: 15 April 2014.

This work is licensed under a Creative Commons Attribution NonCommercial 3.0 License (CC BY-NC 3.0).

(C) Copyright F. Nugnes and G. Viggiani, 2014

Licensee PAGEPress, Italy

Entomologia 2014; 2:176

doi:10.4081/entomologia.2014.176

\section{Introduction}

Some years ago, one of the authors (G.V.) started to study egg parasitoids of leafhoppers (Cicadellidae), mostly in southern Italy. Efforts were made to collect members of Anagrus Haliday (Hymenoptera: Mymaridae) from wild and cultivated host plants, and possibly from known insect hosts. Most of the collected species belonged to the atomus species group as defined by Chiappini (1989). Their morphology and phenology were studied in relation to some agroecosystems (Viggiani, 1991; 2009; Viggiani et al., 2003; 2004a; 2004b; Viggiani \& Jesu, 2005; Matteucig \& Viggiani, 2008; Velocci \& Viggiani, 2008). Taxonomic discrimination of $A$. atomus (Linnaeus) and $A$. ustulatus Haliday (sensu Chiappini, 1989) was not confirmed by molecular analysis of ITS2 and COI, but in this complex a clade corresponding to Anagrus ustulatus from eggs of Lindbergina aurovittata (Douglas) on Quercus ilex L. was clearly distinct (Monti et al., 2009). This evidence suggested a more in-depth morphological analysis and molecular characterization, integrated with extensive biological data (Nugnes, 2011; Nugnes et al., 2011). In this paper the Anagrus species reared from $L$. aurovittata on $Q$. ilex is recognized and described as a new species belonging to the atomus species group.

Anagrus presently includes 92 valid species (Noyes, 2013); only 19 of them are included in the atomus species group of $A$. (Anagrus Haliday). The atomus group was defined in different ways (Graham, 1982; Chiappini, 1989; Chiappini et al., 1996), but the main discriminating character is the presence of only 3 multiporous plate sensilla (mps) on the antennal club of females.

\section{Materials and Methods}

Leaves of $Q$. ilex were randomly collected in several locations of Campania (mostly in Portici, NA, and in Vietri sul Mare, SA) and in Basilicata (Rivello, PZ). In the laboratory the parasitised eggs of $L$. aurovittata were individually isolated with a small piece of leaf tissue in a microcapsule (diameter 15 and height $15 \mathrm{~mm}$ ). The leafhopper host was previously identified according to features of the male genitalia, as illustrated by Vidano et al. (1990). Emerged parasitoids of Anagrus were slide-mounted in Canada balsam phenol. Samples of specimens caught by sticky yellow traps, placed in the $Q$. ilex woodland of Parco Gussone (Portici), from October 2011 to June 2013, were also slide-mounted. All the material was examined under a Zeiss Axiophot microscope and measurements were taken and given in $\mu \mathrm{m}$. Terminology used in this article follows Gibson (1997), Huber (2012) and Debauche (1948) for forewing macrosetae.

From December 2009 to April 2010, 3 yellow sticky traps (Glutor, 
$13 \times 24 \mathrm{~cm}$ ) were installed at a distance of about $30 \mathrm{~m}$ from each other in a $Q$. ilex woodland at Portici (50 m elevation) and removed every two weeks. From October 2011 to June 2013 traps of the same type were placed in the same area, but removed weekly. In the laboratory each trap was examined, the adults of Anagrus and those of $L$. aurovittata were recorded.

Samples of $100 Q$. ilex leaves were taken at random each week in the same woodland from November 2009 to April 2010. On each leaf the eggs (healthy and parasitised) and the young stages of $L$. aurovittata were recorded. Two samples, each of 50 leaves, were randomly taken on 2.x.2009 and 11.iii.2011 for evaluation of degree of infestation by $L$. aurovittata and the percentage parasitism of their eggs by Anagrus.

Adult emergence of Anagrus and L. aurovittata in the field was also followed by marking some eggs on $Q$. ilex leaves and examining them weekly.

\section{Anagrus spp. examined for the morphometric analysis}

Anagrus atomus (Linnaeus). From eggs of Ficocyba ficaria (Horvath) in leaves of Ficus carica L.: 7ㅇ, Torrecuso (BN), 2.vii.2004, coll. A. Di Luca; $2+$, same place and collector, 8.vii.2004; 1 , , same place and collector, 12.vii.2004; 1 , same place and collector; 1 , , Tramonti (SA), 13.vii.2004, same collector; 1 , , Torrecuso, 14.vii.2004, coll. A. Di Luca; 3 , , Tramonti, 21.vii.2004, coll. A. Di Luca; 3 , same place and collector, 29.vii.2004; 1ㅇ, same place and collector, 1.ix.2004. From eggs of Zyginidia pullula (Boheman) in leaves of Zea mays L.: 2 , Brescia, 9.vii.2004, coll. I. Rigamonti; 7 , same place and collector, 13.vii.2004; $1 \circ$, Beregazzo con Figliaro (C0), 4.viii.2004, same collector; 1ㅇ, Brescia, 13.viii.2004, same collector; 7 , Rovellasca (C0), 13.viii.2004, same collector; 2 , same place and collector, 25.viii.2004; $2 \hat{\jmath}$, Tramonti, 26.vi.2004, from leafhopper egg in fig leaf, coll. G. Viggiani; $1 \widehat{\jmath}$, Torrecuso, 12.vii.2004, same host, coll. L. Rillo; $2 \hat{\jmath}$, Brescia, 30.vii.2004, from leafhopper eggs in corn leaves, coll. I. Rigamonti; $4 \widehat{ }$ Rovellasca, 4.viii.2004, same host and collector; $4 \hat{\diamond}$, same place, host and collector, 25.viii.2004; $2 \lesssim$, Portici, 19.vi.2007, from leafhopper eggs of Eupteryx sp. in Salvia leaves, coll. G. Matteucig; $1 \lesssim$, same place, host and collector, 9.vii.2007.

Anagrus ustulatus Haliday (sensu Chiappini, 1989). From eggs of leafhoppers on bramble (Rubus ulmifolius L.) (Viggiani et al., 2004b):

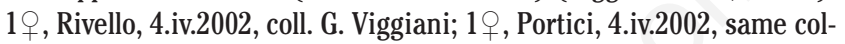
lector; 4 , Rivello, 14.iv.2002, same collector; 1 , , same place and collector, 28.iv.2002; 1ㅇ, Marcianise (CE), 2.v.2002, same collector; 1 , Portici, 5.xi.2002, same collector; $3 \circ$, Ghemme (NO), 18. xii.2002, coll. I. Rigamonti; 1 , Domicella (AV), 25.ii.2004, coll. G. Viggiani; $2 \circ$, Domicella, 7.iii.2004, same collector; 1 , Domicella, 8.iii.2004, same collector; $2 \circ$, Domicella, 22.iii.2004, same collector; $2 \circ$, same place and collector, 22.iii.2004; 1 , , Domicella, 27.iii.2004, coll. A. Di Luca; $1 \bigcirc$, same place, 31.iii.2004, coll. G. Viggiani; $2 \circ$, same place and collector, 2.iv.2004; 1 \%, Napoli-S.Giovanni a Teduccio, 8.iv.2004, coll. R. Sasso; 1 9 , Domicella, 13.iv.2004, coll. A. Di Luca; $1+$, Domicella, 17.iv.2004, coll. G. Viggiani; 2 , Domicella, 20.iv.2004, same collector; $1+$, Napoli-S.Giovanni a Teduccio, 20.iv.2004, same collector; 2 , Domicella, 24.iv.2004, coll. G. Viggiani; 19 , same place and collector, 27.iv.2004; 1 , , same place and collector, 31.iv.2004; 1 , , Torre le Nocelle (AV), 3.v.2004, same collector; 1 \% , Domicella, 6.v.2004, coll. A. Di Luca. From leafhoppers eggs on rose (Rosa sp.), probably of Edwardsiana rosae (Linnaeus): 1 , Matraia (LU), 11.i.2005, coll. V. Mazzoni; 4 , same place and collector, 24.i.2005; 1 , , same place and collector, 3.ii.2005; 3 ㅇ, same place and collector, 10.ii.2005; 1 , same place and collector, 24.ii.2005; 7 , same place and collector, 28.ii.2005. From eggs of leafhoppers on grapes (Vitis vinifera L.) (Viggiani et al., 2004a): 1 , Riparbella (PI), 1.vi.2002, coll. V. Mazzoni; $1+$, Napoli-S. Giovanni a Teduccio, 23.vii.2002, coll. R. Sasso; 1q, Riparbella, 1.viii.2002, coll. V. Mazzoni; 21 , S. Giorgio a Cremano (NA), 12.ix.2002, coll. R. Sasso; 2 , same place and collector, 3.x.2002; 2 ,
Riparbella, 21.x.2002, coll. V. Mazzoni; 19 , S. Giorgio a Cremano, 27.x.2002, coll. R. Sasso; 1 9 , same place and collector, 29.x.2002; 3 , same place and collector, 5.xi.2002; 2 , Riparbella, 8.xi.2002, coll. V. Mazzoni; 1ㅇ, S. Giorgio a Cremano, 10.xi.2002, coll. R. Sasso; 1 , Riparbella, 24.vi.2004, coll. V. Mazzoni; 1 9 , same place and collector, 3.viii.2004; 4 , same place and collector, 12.viii.2004; 9 , same place and collector, 24.viii.2004; 3 , same place and collector, 31.viii.2004; 11 , , same place and collector, 14.ix.2004; 4 , same place and collector, 23.ix.2004; 4 , , same place and collector, 5.x.2004. From leafhopper eggs on bramble: $3 \hat{\jmath}$, Asciano (SI), 7.ii.2005, coll. V. Mazzoni; $2 \hat{\jmath}$, Cisanello (PI), 10.ii.2005, same collector; $2 \hat{\jmath}$, Asciano, 3.iii.2005, coll. same collector; $3 \hat{\jmath}$, same place and collector, 7.iii.2005; $1 \hat{\delta}$, same place and collector, 14.iii.2005; $2 \hat{\diamond}$, Cisanello, 14.iii.2005, same collector; $2 \hat{\diamond}$, Matraia, 7.iii.2005, same collector; $4 \hat{\jmath}$, same place and collector,

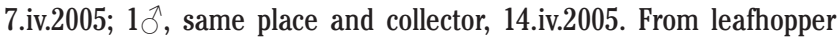
eggs on grape leaves: $2 \hat{\jmath}$, S.Giorgio a Cremano, 5.ix.2002, coll. R. Sasso; $2 \hat{\jmath}$, Riparbella, 9.ix.2002, coll. V. Mazzoni; $1 \hat{\jmath}$, same place and

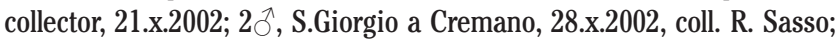
$1 \lesssim$, Riparbella, 28.viii.2003, coll. V. Mazzoni; $1 \delta$, same place and collector, 24.vi.2004; $1 \hat{\partial}$, same place and collector, 12 .viii.2004; $1 \hat{\jmath}$, same place and collector, 31.viii.2004; $6 \AA$, same place and collector, 14.ix.2004; $3 \hat{\text {, }}$ same place and collector, 5.x.2004. From leafhopper eggs on rose leaves: $5 \hat{\jmath}$, Matraia, 24.i.2005, coll. V. Mazzoni; $1 \hat{\jmath}$, same place and collector, 3.ii.2005; $2 \hat{\jmath}$, same place and collector, 10.ii.2005; $1 \hat{\jmath}$, same place and collector, 24.ii.2005; $2 \AA$, same place and collector, 28.ii.2005.

\section{Results}

\section{Taxonomy}

\section{Anagrus lindberginae Nugnes et Viggiani, sp. $\mathrm{n}$.}

HoLOTYPE + , slide-mounted and labeled as follows: Italy. Campania, Portici (NA), Parco Gussone (4048'45.66”N 14²0’46.12”E), from egg of Lindbergina aurovittata on Quercus ilex, 7.iii. 2003, coll. G. Viggiani. Paratypes: 4 , Portici, 3. iii, 2003, same host and collector; $15+$, Portici, 7.iii. 2003, same host and collector; 1 , , Portici, 20.i.2010, same host, coll. F. Nugnes; 1 , Portici, 12.i.2011, same host and collector; 1 , Portici, 17.iii.2012, same host and collector; 1 \% , Portici, 22.iii.2012, same host and collector; 1 , Portici, 25.iii.2012, same host and collector; $1 \propto$ and $1 \lesssim$, Portici,12.ii.1985, from eggs of L. aurovittata in leaves of Myrtus communis, coll. G. Viggiani. The paratypes are all slide-mounted.

ADDITIONAL MATERIAL: From egg of $L$. aurovittata in leaves of $Q$. ilex: $1+$, Portici, 18.ii.2006, coll. G. Viggiani; 1 , , same place, 11.iii.2011, coll. G. Viggiani. From leafhopper eggs, probably of $L$. aurovittata, in

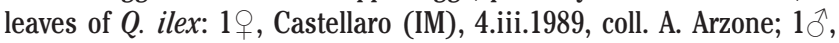
Pino Torinese (T0), 15.ii.1990, same collector; 2 , Castellaro, 28.v.1990, same collector. From eggs of $L$. aurovittata in leaves of Myrtus communis L. 5 9 , Portici,7.iii.2003, coll. G. Viggiani; 2 , 14.iii.2005, same place and collector,; 1 ,, 15 .iii.2005, same place and collector. From yellow sticky traps: $13 \circ$, Portici, 22-29.i.2003, coll. G. Viggiani; $5 \circ$, same place and collector, 5.ii.2003; $1 \hat{\delta}$, same place and collector, 12.ii.2003; 1 , , same place and collector, 12.ii.2003; 12 , same place and collector, 5.iii.2003; $6 \circ$, same place and collector, 26.iii.2003; $1 \hat{\delta}$, same place and collector, 19.xii.2011; $1 \hat{\delta}$, same place and collector, 16.i.2012; $1 \widehat{\delta}$, same place and collector, 28.i.2012; $1 \delta^{\lambda}$, same place and collector, 26.iii.2012; $1 \hat{\jmath}$, same place and collector, 9.iv.2012; $1 \hat{\jmath}$, same place and collector, 27.xi.2012. All specimens of the additional material are slide-mounted.

HoLOTYPE, $3 \rightarrow$ paratypes and all additional material are deposited in the entomological collection of the Dipartimento di Agraria dell'Università degli Studi Federico II, Portici, Napoli, Italia; 2 + paratypes (Portici, 7.iii. 2003, from egg of Lindbergina aurovittata on Quercus ilex, 7.iii. 2003, coll. G. Viggiani) in the National History 
Museum, London, England, U.K.; $2 \odot$ paratypes (Portici, 7.iii. 2003, from egg of Lindbergina aurovittata on Quercus ilex, 7.iii. 2003, coll. G. Viggiani) in the University of California, Riverside, USA; $2 \odot$ paratypes (Portici, 7.iii. 2003, from egg of Lindbergina aurovittata on Quercus ilex, 7.iii. 2003, coll. G. Viggiani) in the National Museum of Natural History, Washington, D. C. and 29 paratypes (Portici, 7.iii. 2003, from egg of Lindbergina aurovittata on Quercus ilex, 7.iii. 2003, coll. G. Viggiani) in Canadian National Collection of Insects, Ottawa, Ontario.

\section{Diagnosis}

FEMALE. Brown, head and pronotum darker. Antenna (scape, pedicel, F1-F4), scutellum and frenum, and legs, yellowish or light brown. Wings with infuscation on the area behind the venation. Body length: 400-500 $\mu \mathrm{m}$ (mean: $465 \mu \mathrm{m}$; SD: $\pm 47.4 ; \mathrm{n}=10$ ). Head wider than high (1.25). Antenna (Figure 1A) with scape as wide as pedicel, but longer (1.8); F1 slightly longer than wide and narrow, about half of pedicel, F2 longer than F1 (2.16) and subequal to F4; F3 slightly shorter; F5 slightly wider than the previous segment and shorter than F6; club around twice the length of F6. Antennal segments with sparse setae, increasing in density from scape to club; F5 and F6 with one-two mps; club with $3 \mathrm{mps}$.

Mesosoma shorter than metasoma (ratio: 0.732; SD: \pm 0.0674 ; $n=$ 10). Pronotum with subpolygonal sculpture. Mesoscutum with mid lobe about as long as wide, with weakly raised sculpture, without setae. Forewing (Figure 1B) longer than body (mean: $749 \mu \mathrm{m}$; SD: \pm 48.6 ; $\mathrm{n}=10$ ), (length/width ratio: $8.76 \mathrm{SD}: \pm 0.7211 ; \mathrm{n}=10$ ); venation as in Figure 1C; ratio of distal macrochaeta length/proximal macrochaeta length variable, 2.72-7.20 (mean: 3.83: SD: \pm 1.008 ; $n=20$ ); disc at broadest part with 2-4 longitudinal rows of setae above an oval hairless area; longest marginal cilia/the maximum discal width ratio: 3.518 (SD: $\pm 0.2959 ; \mathrm{n}=10$ ). Hind wing with a row of small setae along the posterior margin and an incomplete row of 4-6 setae on the distal half of the

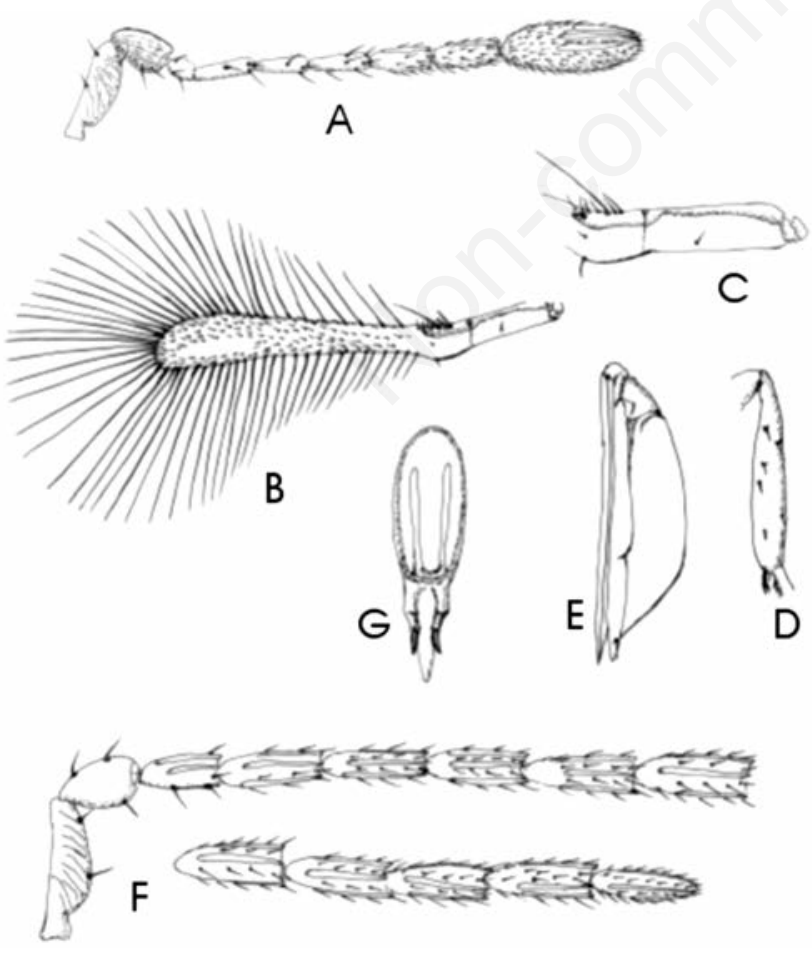

Figures 1. Anagrus lindberginae sp. n. Female. A) antenna; B) forewing; C) details of venation; D) fore tibia; E) ovipositor. Male. F) antenna; G) genitalia. anterior margin. Legs: fore tibia (Figure 1D) shorter than middle and hind tibiae (average ratio: 1:1.3:1.5; $\mathrm{n}=20$ ); tarsomeres, 2.3 times as long as wide; basitarsomere of foreleg slightly longer.

Metasoma sublaterally with two groups of two setae on terga IV-VII, and one group of 2 setae on tergum VIII; cercal plate with 3 subequal long setae and 1 about one half their length. Ovipositor slightly exserted beyond apex of gaster. Ratio of total ovipositor length/length of fore tibia (Figure 1D, E): 1.4-1.6 (mean: 1.52; SD: \pm 0.064 ; $n=36$ ). Ratio of length of the ovipositor/length of third valvula: 1.7-2.2 (mean: 2.04; SD: $\pm 0.144 ; n=10$ ); third valvula with one short subapical seta.

MALE. Similar to female in colour, but a little darker. Body length: 400$500 \mu \mathrm{m}$. Antenna (Figure 1F) 13-segmented, with transversely ridged scape 2.02.5 times as long as wide, pedicel as long or slightly shorter than F1, flagellar segments with F1 shorter than F2, subsequent segments subequal, 2 times as long as wide, with last three segments a little longer. Flagellar segments with sparse setae and each with 2-3 mps. Male genitalia (Figure 1G) as in A. atomus (Viggiani 1970), with the aedeagus body a little longer than the apodemes. Length: $82-105 \mu \mathrm{m}$ (mean: 93; SD: $\pm 6.5 ; \mathrm{n}=9$ ).

Етумоцоgу. The specific name lindberginae refers to the leafhopper host genus.

Distribution. The new species is recorded from Campania, Liguria and Piedmont in Italy. The A. atomus referred by Bosco \& Arzone (1991) as parasitoid of Lindbergina spp. is to be considered A. lindberginae (voucher specimens examined by G.V.).

REMARKS. In the key to Holarctic species of Anagrus (Chiappini et al., 1996), A. lindberginae goes to the same couplet as A. longitibialis Donev, the only other known European species that has the same ovipositor/fore tibia ratio (1.5-1.6), but A. longitibialis differs by having a mps on both F3 and F4. However, it is A. ustulatus sensu Chiappini that the new species resembles the most. It differs morphologically from this species by the ratios ovipositor length/fore tibia and ovipositor length/third valvula.

The most common species of the A. atomus group allied to A. lindberginae are A. atomus and A. ustulatus (sensu Chiappini, 1989). Morphometric data on females of these Anagrus species were given by Chiappini (1987). According to Chiappini et al. (1996) females of $A$. atomus can be distinguished by the following combination of features: club with three mps, F3 without mps, F4 with one mps; ovipositor/fore tibia ratio about 2.0; mesoscutum without setae; forewing with three irregular rows of discal hairs in basal half, and three or four rows anterior to hairless area, hairless area at broadest part of forewing short, FWL/FWW <10. In the description of the neotype of $A$. atomus, Chiappini \& Triapitsyn (2007) add other characters to the diagnosis of A. atomus: F2 a little longer than F3; club a little longer than two preceding segments combined; forewing 6.8 times as long as wide; distal macrochaeta about 2.5 times the length of the proximal macrochaeta.

Anagrus ustulatus Haliday (1833, p. 347) was described as follows: Sp. 3. A. ustulatus. Fuscus antennis thoracis disco pedibusque ferrugineis, alis hyalinis. $\hat{\sigma}$ (Long. 0.03; alar. 0.08.). Precedentibus brevior, colore obscuriore; alae ut in A. atomo. Graham (1982, p. 201) stated that of the seven specimens that stand under this name in Haliday's collection, but all except the first two (Nos. 70 and 71) are females. No 70 agrees with the original description and is now designed LECTOTYPE. He stated that the females were clearly conspecific with the male lectotype and did not accept the synonymy of $A$. ustulatus with A. atomus proposed by Debauche (1948). In his key Graham (1982, p. 198) stated that ustulatus shows forewing very broad for the genus 5.7-6.1 times as long as broad and with 8-9 longitudinal rows of hairs in its distal part. Chiappini (1989) recognised that her Anagrus sp. obtained from leafhoppers on bramble and rose is conspecific with A. ustulatus. However, that species does not fit with the characters given by Graham in his key. In A. ustulatus sensu Chiappini the ratio of forewing length/forewing width is 8.237 (9.400-7.200) and the rows of hairs on 
the discal area are 4-5. But according to Graham (1982, p. 201) the genitalia of the lectotype male of ustulatus are unlike those of atomus but similar to the type found in the incarnatus species-group; according to Chiappini (1989, p. 104) the genitalia of A. ustulatus are typical of atomus group. That does not help to characterize the species properly. The situation is worse for the female of A. ustulatus, which Graham (1982) considered a species sola and did not include in the atomus speciesgroup. In fact, of the 5 female specimens standing under this name in Haliday collection the two numbered 72 and 73 belong to $A$. incarnatus Haliday (Chiappini and Triapitsyn, 2007). In conclusion, the validity of A. ustulatus Haliday remains uncertain. For an attempt at clarification the genitalia of the male lectotype and all females under this name in Haliday's collection need to be properly slide-mounted and studied. One of the present authors (G.V.) is doing this.
Our morphometric data (Tables 1-3) on several populations of A. atomus and A. ustulatus sensu Chiappini show that morphological discrimination of the female may be substantially based only on the presence or absence of a sensory ridge on F4; intermediate forms are rather rare. The other characters reported by Chiappini and Triapitsyn (2007) (ratio of F2/F3; ratio of club length/F5+F6 length; ratio of forewing length/forewing width; ratio of distal macrochaeta length/proximal macrochaeta length; number of hair rows on forewing disc, extension of hairless area at broadest part of forewing; ovipositor/fore tibia ratio) are widely variable and overlapping.

Very limited information is available about the morphological characters of males of the atomus group. Some measurements on the male genitalia are reported by Chiappini and Mazzoni (2000) and Floreani et al. (2006). They show no significant differences for distinguishing $A$.

Table 1. Morphometric measurements of Anagrus antenna (20 females) (in $\mu \mathrm{m})$.

\begin{tabular}{|c|c|c|c|c|}
\hline \multirow[t]{2}{*}{ Measure } & Length (mean \pm SD) & Width (mean \pm SD) & Length (mean \pm SD) & Width (mean \pm SD) \\
\hline & \multicolumn{2}{|c|}{ A. atomus from corn leaves } & \multicolumn{2}{|c|}{ A. ustulatus from bramble } \\
\hline Scape & $80 \pm 5.1$ & $24 \pm 2.2$ & $70 \pm 5.3$ & $24 \pm 3.0$ \\
\hline Pedicel & $41 \pm 2.0$ & $27 \pm 2.3$ & $39 \pm 3.2$ & $27 \pm 2.4$ \\
\hline $\mathrm{Fl}$ & $18 \pm 1.7$ & $15 \pm 0.0$ & $17 \pm 2.2$ & $13 \pm 2.5$ \\
\hline $\mathrm{F} 2$ & $48 \pm 2.9$ & $13 \pm 2.0$ & $39 \pm 4.2$ & $11 \pm 2.2$ \\
\hline F3 & $44 \pm 3.2$ & $11 \pm 1.4$ & $34 \pm 4.9$ & $11 \pm 1.7$ \\
\hline F4 & $52 \pm 3.7$ & $15 \pm 1.8$ & $40 \pm 4.3$ & $12 \pm 2.3$ \\
\hline F5 & $54 \pm 4.1$ & $16 \pm 2.2$ & $45 \pm 4.5$ & $17 \pm 2.4$ \\
\hline $\mathrm{F} 6$ & $56 \pm 3.5$ & $20 \pm 1.7$ & $50 \pm 5.1$ & $19 \pm 2.6$ \\
\hline \multirow[t]{2}{*}{ Club } & $100 \pm 3.2$ & $32 \pm 2.9$ & $99 \pm 7.2$ & $31 \pm 3.1$ \\
\hline & \multicolumn{2}{|c|}{ A. atomus from fig leaves } & \multicolumn{2}{|c|}{ A. ustulatus from grape leaves } \\
\hline Scape & $87 \pm 6.3$ & $25 \pm 1.6$ & $68 \pm 4.1$ & $23 \pm 2.5$ \\
\hline Pedicel & $38 \pm 2.7$ & $27 \pm 2.9$ & $38 \pm 2.5$ & $25 \pm 1.3$ \\
\hline F1 & $16 \pm 2.3$ & $11 \pm 2.3$ & $16 \pm 2.9$ & $13 \pm 2.1$ \\
\hline $\mathrm{F} 2$ & $37 \pm 3.8$ & $12 \pm 2.3$ & $35 \pm 2.8$ & $11 \pm 1.8$ \\
\hline F3 & $33 \pm 4.6$ & $10 \pm 1.3$ & $29 \pm 2.2$ & $10 \pm 0.5$ \\
\hline $\mathrm{F} 4$ & $44 \pm 5.5$ & $15 \pm 1.3$ & $36 \pm 3.3$ & $12 \pm 2.2$ \\
\hline F5 & $48 \pm 3.7$ & $15 \pm 1.6$ & $43 \pm 3.4$ & $16 \pm 2.3$ \\
\hline $\mathrm{F} 6$ & $50 \pm 4.3$ & $19 \pm 1.7$ & $48 \pm 3.0$ & $19 \pm 2.3$ \\
\hline \multirow[t]{2}{*}{ Club } & $98 \pm 5.1$ & $30 \pm 2.9$ & $95 \pm 5.3$ & $31 \pm 2.3$ \\
\hline & \multicolumn{2}{|c|}{ A. lindberginae } & \multicolumn{2}{|c|}{ A. ustulatus from rose leaves } \\
\hline Scape & $71 \pm 3.1$ & $25 \pm 0.7$ & $69 \pm 3.5$ & $25 \pm 0.0$ \\
\hline Pedicel & $44 \pm 3.4$ & $26 \pm 2.3$ & $41 \pm 2.6$ & $28 \pm 2.3$ \\
\hline Fl & $20 \pm 1.1$ & $14 \pm 1.8$ & $17 \pm 2.2$ & $13 \pm 2.0$ \\
\hline $\mathrm{F} 2$ & $47 \pm 2.9$ & $14 \pm 2.9$ & $39 \pm 4.1$ & $12 \pm 2.0$ \\
\hline F3 & $40 \pm 4.4$ & $11 \pm 1.4$ & $33 \pm 3.6$ & $11 \pm 1.3$ \\
\hline $\mathrm{F} 4$ & $46 \pm 3.7$ & $14 \pm 1.9$ & $39 \pm 3.8$ & $13 \pm 2.1$ \\
\hline F5 & $51 \pm 4.0$ & $15 \pm 1.5$ & $46 \pm 3.5$ & $19 \pm 2.1$ \\
\hline F6 & $53 \pm 2.5$ & $19 \pm 1.6$ & $49 \pm 2.2$ & $20 \pm 6.2$ \\
\hline Club & $103 \pm 4.3$ & $32 \pm 8.7$ & $100 \pm 3.5$ & $32 \pm 3.0$ \\
\hline
\end{tabular}

Table 2. Morphometric measurements (mean $\pm \mathrm{SD}$ ) of Anagrus forewing (20 females).

\begin{tabular}{lcccccc} 
& FWL & DW & FL & FWL/DW & FLDW & DML/PML \\
A. atomus from corn leaves & $535 \pm 23.0$ & $57 \pm 5.5$ & $175 \pm 9.4$ & $9.40 \pm 0.644$ & $3.09 \pm 0.326$ & $4.05 \pm 0.614$ \\
A. atomus from fig leaves & $480 \pm 32.5$ & $55 \pm 4.8$ & $163 \pm 9.7$ & $8.79 \pm 0.425$ & $2.97 \pm 0.216$ & $2.61 \pm 0.368$ \\
\hline A. lindberginae & $563 \pm 34.3$ & $66 \pm 5.9$ & $209 \pm 10.5$ & $8.55 \pm 0.586$ & $3.17 \pm 0.328$ & $3.83 \pm 1.008$ \\
A. ustulatus from bramble & $508 \pm 44.3$ & $68 \pm 10.1$ & $180 \pm 15.7$ & $7.60 \pm 0.765$ & $2.70 \pm 0.422$ & $3.23 \pm 0.553$ \\
\hline A. ustulatus from grape leaves & $439 \pm 27.5$ & $54 \pm 5.0$ & $159 \pm 7.6$ & $8.26 \pm 0.645$ & $2.92 \pm 0.290$ & $3.04 \pm 0.605$ \\
A. ustulatus from rose leaves & $524 \pm 24.8$ & $71 \pm 1.4$ & $208 \pm 12.4$ & $7.42 \pm 0.394$ & $2.94 \pm 0.253$ & $2.98 \pm 0.420$ \\
\hline
\end{tabular}

DML/PML, distal macrochaeta length/proximal macrochaeta length; DW, discal width; FL, fringe length; FL/DW, fringe maximum length/discal width; FWL, forewing length; FWL/DW, forewing length/discal width. 
atomus from A. ustulatus sensu Chiappini. Our data concerning the antenna, forewing, male genitalia of above-mentioned species and those of $A$. lindberginae (Tables 4-6) confirm the present impossibility to distinguish their males on a morphological basis.

Another allied species, and possibly a junior synonym of $A$. ustulatus sensu Chiappini, is A. erythroneurae Trjapitzin and Chiappini (De León et al. 2008) although they were shown to differ genetically.

At present, females of the European species of the atomus group can be keyed as follows:

1. Antenna with a mps on F3 and/or F4 . .2

Antenna without a mps on F3 and/or F4 . .3

2. Antenna with a mps on F3 and F4; ovipositor length/fore tibia length ratio $1.5-1.6$ A. longitibialis Donev
- $\quad$ Antenna without a mps on F4; ovipositor/fore tibia ratio 1.9-2.0........ A. atomus (Linnaeus)

3. Ovipositor length/fore tibia ratio 1.8-2.2; fore tibia length/third valvula length ratio $1.26-1.60$.

.A. ustulatus sensu Chiappini (nec Haliday, 1833)

- $\quad$ Ovipositor length/fore tibia length ratio 1.4-1.6; fore tibia length /third valvula length ratio 1.9-2.1

A. lindberginae Nugnes et Viggiani

The species $A$. ustulatus sensu Chiappini (1989) should be referred to A. parvus Soyka (1955). At present Anagrus ustulatus Haliday 1833 , based on a lectotype male, revised by Graham (1982) and Chiappini (1989), can not be definitely linked to any female species of the atomus group of Anagrus.

Table 3. Morphometric measurements (mean $\pm \mathrm{SD}$ ) of the Anagrus ovipositor (20 females).

\begin{tabular}{lccccc} 
& OL & FIL & OL/FTL & V3L & \\
A. atomus from corn leaves & $236 \pm 8.6$ & $120 \pm 6.1$ & $1.97 \pm 0.113$ & $82 \pm 4.7$ & $1.45 \pm 0.085$ \\
\hline A. atomus from fig leaves & $227 \pm 18.3$ & $111 \pm 9.0$ & $2.03 \pm 0.102$ & $83 \pm 5.7$ & $1.34 \pm 0.105$ \\
A. lindberginae & $194 \pm 11.0$ & $125 \pm 5.5$ & $1.54 \pm 0.093$ & $61 \pm 3.3$ & $2.02 \pm 0.064$ \\
\hline A. ustulatus from bramble & $214 \pm 15.5$ & $109 \pm 11.0$ & $1.97 \pm 0.114$ & $74 \pm 2.6$ & $1.46 \pm 0.117$ \\
A. ustulatus from grape leaves & $208 \pm 10.2$ & $99 \pm 4.1$ & $2.10 \pm 0.092$ & $73 \pm 4.7$ & $1.36 \pm 0.099$ \\
\hline A. ustulatus from rose leaves & $218 \pm 9.5$ & $113 \pm 5.8$ & $1.91 \pm 0.091$ & $74 \pm 4.3$ & $1.49 \pm 0.112$ \\
\hline
\end{tabular}

FTL, fore tibia length; OL, ovipositor length; OL/FTL, ovipositor length/fore tibia length; OLN3L, ovipositor length/third valvula length; V3L, third valvula length.

Table 4. Morphometric measurements of Anagrus male antenna (16 A. atomus, 9 A. lindberginae, 20 A. ustulatus from bramble, 20 A. ustulatus from grape leaves, and 11 A. ustulatus from rose leaves).

\begin{tabular}{|c|c|c|c|c|c|c|}
\hline \multicolumn{3}{|c|}{ A. atomus } & \multicolumn{2}{|c|}{ A ustulatus from bramble } & \multicolumn{2}{|c|}{ A. ustulatus from rose leaves } \\
\hline Scape & $62 \pm 4.5$ & $23 \pm 2.9$ & $59 \pm 2.8$ & $23 \pm 2.3$ & $61 \pm 3.7$ & $23 \pm 3.0$ \\
\hline Pedicel & $38 \pm 35$ & $30 \pm 2.2$ & $40 \pm 1.9$ & $29 \pm 1.2$ & $40 \pm 0.0$ & $29 \pm 0.7$ \\
\hline Fl & $35 \pm 4.8$ & $21 \pm 3.1$ & $31 \pm 3.1$ & $21 \pm 1.6$ & $29 \pm 4.7$ & $20 \pm 1.9$ \\
\hline $\mathrm{F} 2$ & $46 \pm 8.5$ & $18 \pm 2.9$ & $39 \pm 4.2$ & $19 \pm 2.1$ & $37 \pm 4.7$ & $18 \pm 2.3$ \\
\hline F3 & $47 \pm 7.1$ & $19 \pm 2.5$ & $39 \pm 4.2$ & $19 \pm 1.7$ & $37 \pm 5.4$ & $18 \pm 2.0$ \\
\hline F4 & $47 \pm 6.5$ & $19 \pm 2.0$ & $39 \pm 3.5$ & $18 \pm 2.5$ & $38 \pm 3.9$ & $17 \pm 2.5$ \\
\hline F5 & $47 \pm 6.3$ & $18 \pm 2.6$ & $40 \pm 3.8$ & $19 \pm 2.6$ & $38 \pm 4.2$ & $19 \pm 2.8$ \\
\hline F6 & $49 \pm 6.0$ & $19 \pm 2.9$ & $42 \pm 3.0$ & $19 \pm 3.1$ & $40 \pm 3.9$ & $19 \pm 3.2$ \\
\hline F7 & $50 \pm 5.3$ & $20 \pm 3.7$ & $42 \pm 3.0$ & $19 \pm 2.8$ & $41 \pm 2.5$ & $19 \pm 3.2$ \\
\hline F8 & $49 \pm 5.2$ & $20 \pm 2.7$ & $43 \pm 3.4$ & $21 \pm 3.1$ & $42 \pm 2.5$ & $20 \pm 2.3$ \\
\hline F9 & $51 \pm 5.0$ & $21 \pm 3.5$ & $44 \pm 2.4$ & $21 \pm 3.0$ & $44 \pm 3.9$ & $20 \pm 3.6$ \\
\hline F10 & $51 \pm 4.5$ & $21 \pm 3.1$ & $45 \pm 1.9$ & $22 \pm 3.2$ & $46 \pm 2.3$ & $21 \pm 3.0$ \\
\hline F11 & $54 \pm 5.5$ & $20 \pm 3.6$ & $49 \pm 4.2$ & $20 \pm 2.3$ & $48 \pm 4.0$ & $19 \pm 2.2$ \\
\hline \multicolumn{3}{|c|}{ A. lindberginae } & \multicolumn{2}{|c|}{ A. ustulatus from grape leaves } & & \\
\hline Scape & $62 \pm 5.6$ & $21 \pm 2.5$ & $57 \pm 3.0$ & $20 \pm 1.5$ & & \\
\hline Pedicel & $38 \pm 2.6$ & $14 \pm 4.1$ & $35 \pm 2.6$ & $27 \pm 2.7$ & & \\
\hline $\mathrm{Fl}$ & $34 \pm 5.3$ & $18 \pm 2.5$ & $29 \pm 2.6$ & $19 \pm 2.0$ & & \\
\hline F2 & $43 \pm 7.9$ & $16 \pm 1.8$ & $37 \pm 5.0$ & $16 \pm 2.2$ & & \\
\hline F3 & $43 \pm 7.0$ & $16 \pm 1.8$ & $37 \pm 4.1$ & $17 \pm 2.4$ & & \\
\hline F4 & $45 \pm 7.0$ & $15 \pm 1.7$ & $37 \pm 3.4$ & $16 \pm 2.3$ & & \\
\hline F5 & $45 \pm 6.6$ & $15 \pm 1.6$ & $38 \pm 4.1$ & $17 \pm 2.4$ & & \\
\hline F6 & $45 \pm 6.1$ & $16 \pm 1.8$ & $39 \pm 3.7$ & $18 \pm 2.7$ & & \\
\hline F7 & $46 \pm 6.2$ & $16 \pm 2.5$ & $40 \pm 3.1$ & $18 \pm 2.7$ & & \\
\hline F8 & $46 \pm 6.1$ & $18 \pm 3.0$ & $40 \pm 3.6$ & $18 \pm 3.5$ & & \\
\hline F9 & $46 \pm 5.8$ & $19 \pm 3.7$ & $43 \pm 3.9$ & $19 \pm 3.2$ & & \\
\hline F10 & $48 \pm 4.6$ & $19 \pm 3.6$ & $43 \pm 2.8$ & $19 \pm 3.9$ & & \\
\hline F11 & $52 \pm 7.0$ & $17 \pm 3.8$ & $45 \pm 3.5$ & $18 \pm 2.7$ & & \\
\hline
\end{tabular}




\section{Host and parasitoid ecology}

In Italy, the leafhopper $L$. aurovittata overwinters as an egg in the leaf of the evergreen plants Q. ilex, Q. suber (Vidano et al, 1990), $M$. communis and R. ulmifolius (Viggiani et al., 2004b; Matteucig and Viggiani, 2008), but also as an adult, as recorded below (Figures 2-4). The most common winter host of L. aurovittata, at least in Campania, is $Q$. ilex. During spring the species completes one generation and new adults leave the winter hosts and spread to plants with deciduous leaves such as some Quercus spp. and Castanea spp. (Viggiani, 1991; 2009). From summer to late autumn the leafhopper can complete more generations. The leafhopper adults then go back on the overwintering hosts and oviposit in subepidermic slits on the leaves, normally by laying single eggs.

The parasitoid Anagrus lindberginae shows a long diapause as a young larva in the host egg (Figure 5), starting from March-April.

From October-November (Figure 6) this stage completes its development in a pupa followed by the adult emergence. These phenological stages of $A$. lindberginae are synchronized with the presence of host

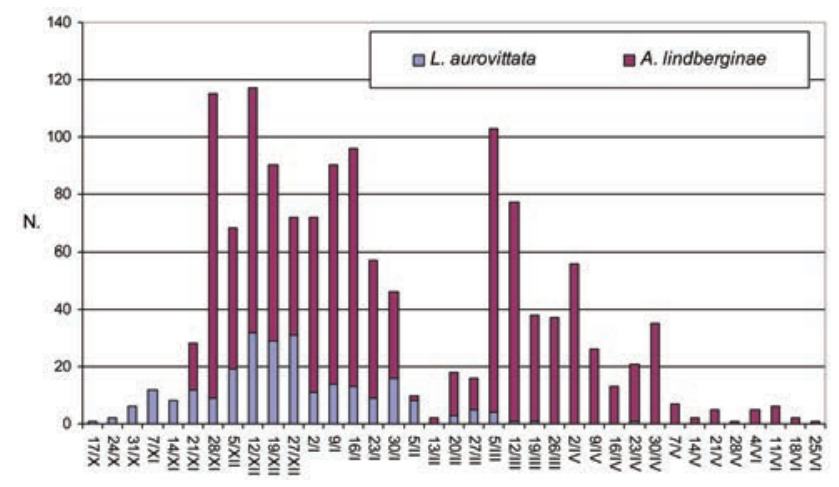

Figure 3. Captures of L. aurovittata and Anagrus by yellow sticky traps disposed in Q. ilex woodland in Portici (Parco Gussone) from October 2011 to June 2012.

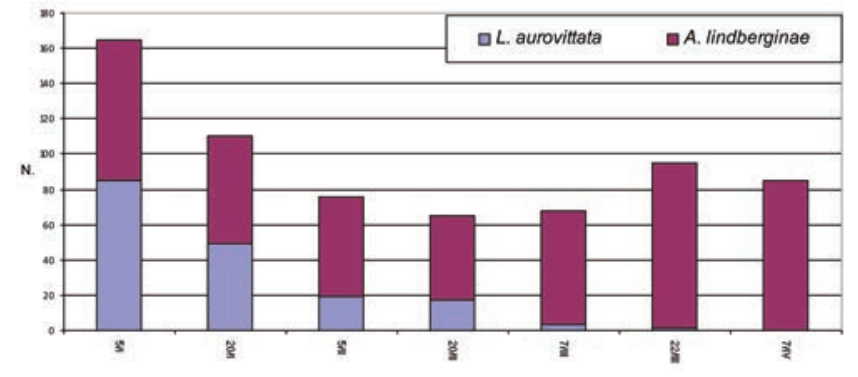

Figure 2. Captures of $L$. aurovittata and A. lindberginae by yellow sticky traps disposed in a $Q$. ilex woodland (Portici, Parco Gussone) from December 21, 2009 to April 7, 2010.

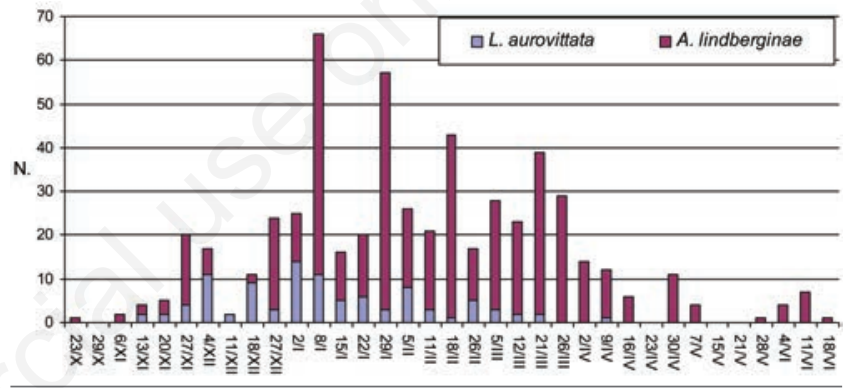

Figure 4. Captures of L. aurovittata and Anagrus by yellow sticky traps disposed in Q. ilex woodland in Portici (Parco Gussone) from October 2012 to June 2013.

Table 5. Morphometric measurements (mean \pm SD) of Anagrus male forewing (16 A. atomus, 9 A. lindberginae, 20 A. ustulatus from bramble, 20 A. ustulatus from grape leaves, and $11 A$. ustulatus from rose leaves).

\begin{tabular}{lcccccc} 
& FWL & DW & FL & FWL/DW & FL/DW & DMIL/PML \\
A. atomus & $561 \pm 43.4$ & $71 \pm 5.4$ & $194 \pm 16.7$ & $7.82 \pm 0.653$ & $2.77 \pm 0.339$ & $4.11 \pm 0.960$ \\
A. lindberginae & $603 \pm 0.8$ & $86 \pm 8.6$ & $224 \pm 11.3$ & $6.99 \pm 0.584$ & $2.60 \pm 0.273$ & $3.56 \pm 0.654$ \\
\hline A. ustulatus from bramble & $533 \pm 30.1$ & $80 \pm 7.2$ & $214 \pm 10.9$ & $6.68 \pm 0.481$ & $2.69 \pm 0.255$ & $3.06 \pm 0.768$ \\
A. ustulatus from grape leaves & $502 \pm 42.6$ & $76 \pm 10.4$ & $195 \pm 16.4$ & $6.61 \pm 0.503$ & $2.56 \pm 0.228$ & $3.34 \pm 0.412$ \\
\hline A. ustulatus from rose leaves & $550 \pm 35.9$ & $83 \pm 4.5$ & $221 \pm 10.8$ & $6.69 \pm 0.566$ & $2.61 \pm 0.115$ & $3.05 \pm 0.366$ \\
\hline
\end{tabular}

DML/PML, distal macrochaeta length/proximal macrochaeta length; DW, discal width; FL, fringe length; FL/DW, fringe maximum length/discal width; FWL, forewing length; FWL/DW, forewing length/discal width.

Table 6. Morphometric measurements (mean \pm SD) of Anagrus male genitalia (16 A. atomus, 9 A. lindberginae, 20 A. ustulatus from bramble, 20 A. ustulatus from grape leaves, and 11 . ustulatus from rose leaves).

\begin{tabular}{lcccccc} 
& GL & PL & PW & EL & BBL & EAL \\
A. atomus & $91 \pm 5.1$ & $52 \pm 5.5$ & $25 \pm 2.5$ & $82 \pm 3.8$ & $43 \pm 1.7$ & $38 \pm 3.0$ \\
A. lindberginae & $93 \pm 9.2$ & $48 \pm 6.2$ & $24 \pm 1.7$ & $86 \pm 5.6$ & $49 \pm 3.8$ & $36 \pm 4.1$ \\
\hline A. ustulatus from bramble & $89 \pm 5.4$ & $48 \pm 3.7$ & $25 \pm 1.3$ & $82 \pm 5.6$ & $47 \pm 4.2$ & $35 \pm 3.8$ \\
A. ustulatus from grape leaves & $89 \pm 9.8$ & $45 \pm 4.0$ & $23 \pm 2.3$ & $81 \pm 8.1$ & $49 \pm 6.4$ & $33 \pm 2.9$ \\
\hline A. ustulatus from rose leaves & $90 \pm 5.4$ & $48 \pm 4.2$ & $24 \pm 3.0$ & $83 \pm 4.5$ & $48 \pm 2.6$ & $35 \pm 2.7$ \\
\hline
\end{tabular}

AAL, aedeagus apodeme length; AL, aedeagus length; ABL, aedeagus body length; GL, Genitalia length; PL, phallobase length; PW, phallobase width. 
new eggs. The parasitoid oviposits in the progressively available host eggs and their young stages develop during winter, when most of the adults emerge (Figures 2-4). They can oviposit in the remaining, left over healthy host eggs, but most of their progeny will start a long diapause period as young larvae from spring to fall. Anagrus lindberginae completes at least one generation from late autumn to early spring.

Over several years it has been confirmed that the population of $A$. lindberginae is represented almost exclusively by females; males are very rare (Viggiani et al., 2003). In the woodland of Parco Gussone (Portici) the percentage of $Q$. ilex leaves with eggs of $L$. aurovittata ranged from 66-54\% (Figure 7); that of the not-parasitised eggs varies from 6.5-37.3\%.

\section{Discussion and Conclusions}

The concept of the atomus group has changed somewhat (Chiappini, 1989; Chiappini et al., 1996; Chiappini \& Mazzoni, 2000). At present this group includes species with $3 \mathrm{mps}$ on the antennal club of females and the genitalia of males, with digiti spines straight or bent. Among the Holarctic species of Anagrus, only 8 species are included in the atomus group. The genotype species, A. atomus, is widespread and rather well characterized (Chiappini \& Triapitsyn, 2007), but the identity of the allied species $A$. ustulatus still remains questionable for the following reasons: i) the poor original description is based on a male, which was designed lectotype (Graham, 1982); ii) no female in the Haliday collection can be definitely associated with the lectotype male; in fact some specimens considered clearly conspecific by Graham (1982) belong to A. incarnatus (Chiappini \& Triapitsyn 2007); iii) the interpretation of $A$. ustulatus given by Chiappini (1989) is uncertain; iv) the very small morphological differences between $A$. atomus and $A$. ustulatus sensu Chiappini (presence or absence of a mps on F4) are not supported by the molecular data (Monti et al., 2009). However Cargnus \& Pavan (2007) have found enzymatic differences between females of $A$. atomus and A. ustulatus reared from the leafhoppers on bramble and grape. Floreani et al. (2006), using the cuticular hydrocarbon analysis, found two distinct profiles for A. atomus and A. ustulatus, classified according to the morphological characters given by Chiappini (1989).

The new species $A$. lindberginae appears morphologically clearly distinguishable among the atomus group species, supported by the molecular data (Monti et al., 2009; Nugnes, 2011). As in a few other species or populations of Anagrus, A. atomus (MacGill, 1934; Choudhury \& Copland 2003), A. delicatus (Cronin \& Strong, 1996), and A. takeyanus (Chiappini et al., 1996), the reproduction of $A$. lindberginae takes place through thelytokous females. The life cycle is well syncronized with that of the host.

In the system $Q$. ilex - L. aurovittata - A. lindberginae two main biological phenomena are involved: migration and diapause. The leafhopper migration in spring from the evergreen hosts to plants with deciduous leaves for reproduction during summer and autumn avoids unfavorable conditions. The larval diapause of $A$. lindberginae allows the parasitoid to survive during a long period in its host's absence. At present, parasitised eggs of $L$. aurovittata by $A$. lindberginae were not recorded in any of the known deciduous host plants of this leafhopper.

A similar case was reported by Tsukada (1999). In Japan, the andromeda lace bug Stephanitis takeyai Drake et Maa (Heteroptera: Tingidae), shows a seasonal host-plant alternation between its main host plants, the evergreen Pieris japonica and the deciduous Lyonia ovalifolia. In some sites where the latter host is rare, the tingid reproduces on $P$. japonica all year around. The seasonal alternative host for $S$. takeyai seems derived from the ancestral non-alternating life cycle. In places were the insect host develop only one generation a year, the egg parasitoid of the tingid, Anagrus takeyanus Gordh and Dunbar, enters in a summer diapause.

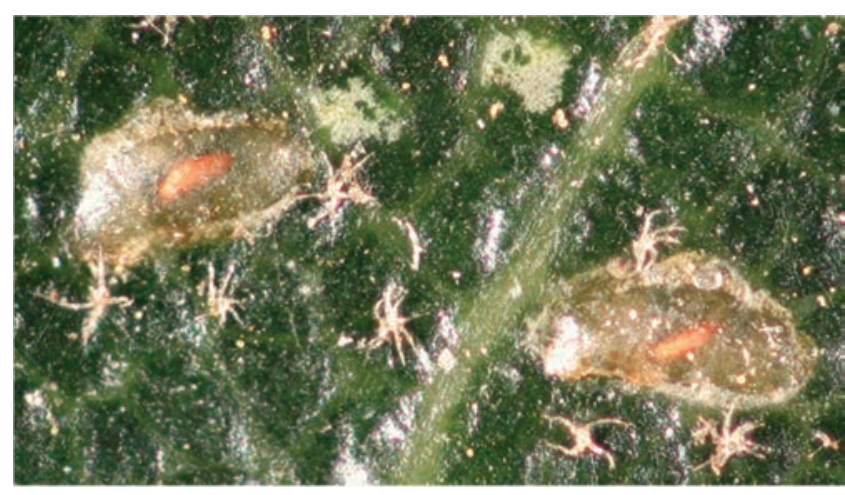

Figure 5. Eggs of L. aurovittata with diapausing larvae (red orange) of $A$. lindberginae.

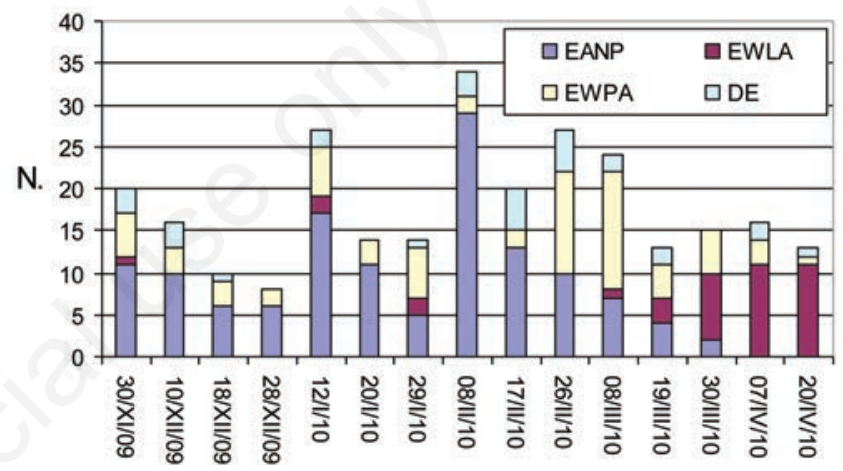

Figure 6. Monitoring of the eggs of L. aurovittata and their parasitism by $A$. lindberginae from November 2009 to April 2010 (Portici, Parco Gussone). Abbreviations: DE=dried eggs. EANP=eggs of $L$. aurovittata apparently not parasitised. EWLA=eggs with larva of $A$. lindberginae. $\mathrm{EWPA}=$ eggs with pupa of $A$. lindberginae.

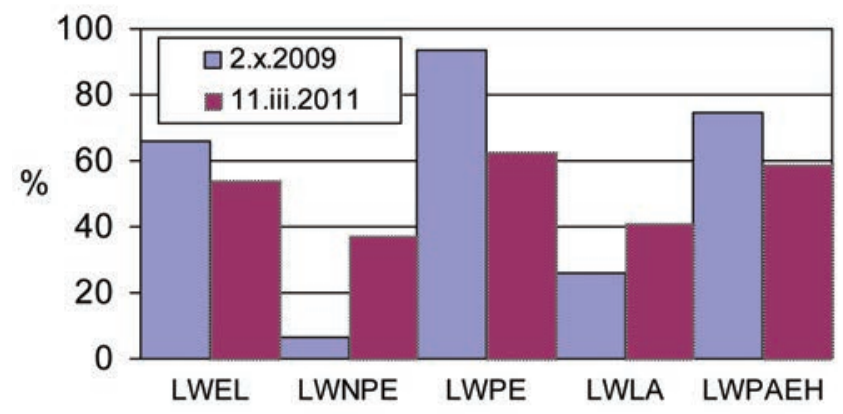

Figure 7. Percentage of $Q$. ilex leaves with eggs of $L$. aurovittata and their rate of parasitism by $A$. lindberginae (Samplings of 2 October 2009 and of 11 March 2011). Abbreviations. LWEL=leaves with eggs of $L$. aurovittata; LWNPE=leaves with non-parasitised eggs of $L$. aurovittata; LWPE=leaves with eggs parasitised by $A$. lindberginae; LWLA=leaves with larvae of $A$. lindberginae in the eggs of $L$. aurovittata; LWPAEH=leaves with pupae of $A$. lindberginae and adult exit hole in the eggs of $L$. aurovittata. 


\section{References}

BOSCO D., ARZONE A., 1991 - Indagini sui parassitoidi oofagi di Lindbergina aurovittata (Douglas) e L. spoliata (Horvath) (Homoptera: Auchenorrhyncha). - Redia 74: 147-162.

CARGNUS E., PAVAN F., 2007 - Potenzialità dell'elettroforesi enzimatica nello studio tassonomico di Anagrus gruppo atomus (Hymenoptera, Mymaridae). XX Cong. Naz. Ital. Entomologia, Campobasso, Italy, 11-16 giugno 2007.

CHIAPPINI E., 1987 - Ricerche sulla variabilità di Anagrus atomus (L.) (Hymenoptera Mymaridae) e di una specie affine presente sul rovo. - Boll. Zool. Agr. Bachicolt. 19: 71-97.

CHIAPPINI E., 1989 - Review of the European species of the genus Anagrus Haliday (Hymenoptera Chalcidoidea). - Boll. Zool. Agr. Bachicolt. 21: 85-119.

CHIAPPINI E., MAZZONI E., 2000 - Differing morphology and ultrastructure of the male copulatory apparatus in species-groups of Anagrus Haliday (Hymenoptera: Mymaridae). - J. Nat. His. 34: 1661-1676.

CHIAPPINI E., TRIAPITSYN S.V., 2007 - Neotype designation for Anagrus atomus (Linnaeus) (Hymenoptera: Mymaridae). - J. Hymenopt. Res. 16: 1-6.

CHIAPPINI E., TRIAPITSYN S.V., DONEV A., 1996 - Key to the Holarctic species of Anagrus Haliday (Hymenoptera: Mymaridae) with a review of the Nearctic and Palaearctic (other than European) species and descriptions of new taxa. - J. Nat. Hist. 4: 551-595.

CHOUDHURY D.A.M., COPLAND M.J.W., 2003 - A new record in thelytoky in the egg parasitoid Anagrus atomus (Linnaeus) (Hymenoptera: Mymaridae). - Pak. J. Biol. Sci. 6: 500-504.

CRONIN J.T., STRONG D.R., 1996 - Genetic of ovoposition success of a thelytokous fairyflay parasitoid, Anagrus delicatus. - Heredity 76 : 43-54.

DE LEÓN J.H., TRIAPITSYN S.V., MATTEUCIG G., VIGGIANI G., 2008 Molecular and morphometric analyses of Anagrus erythroneurae Trjapitzin et Chiappini and Anagrus ustulatus Haliday (Hymenoptera: Mymaridae). - Boll. Lab. Ent. Agr. Filippo Silvestri 62: 19-32.

DEBAUCHE H.R., 1948 - Étude sur les Mymarommidae et les Mymaridae de la Belgique (Hymenoptera-Chalcidoidea). - Mém. Mus. R. Hist. Nat. Belg. 108: 1-248.

FLOREANI C., PAVAN F., NAZZI F., 2006 - Analysis of cuticular hydrocarbons in two Anagrus species (Hymenoptera: Mymaridae) as a tool to improve their correct identification. - Can. Entomol. 138: 348356.

GIBSON G.A.P., 1997 - Morphology and terminology. In: GIBSON G.AP. HUBER J.T., WOOLLEY J.B. (eds). Annotated keys to the genera of Nearctic Chalcidoidea (Hymenoptera). Ottawa, pp 16- 44.

GRAHAM M.W.R.deV., 1982 - The Haliday collection of Mymaridae (Insecta, Hymenoptera, Chalcidoidea) with taxonomic notes on some material in other collections. - Proc. R. Irish Acad. B 82: 189-243.

HALIDAY A.H., 1833 - An assay of the classification of the parasitic Hymenoptera of Britain, which correspond with the Ichneumones minuti of Linnaeus. - Entomol. Mag. 1: 333-350.

HUBER J.T., 2012 - Revision of the genus Ooctonus (Hymenoptera: Mymaridae). - J. Ent. Soc. Ont. 143: 15-105.

MACGILL E.I., 1934 - On the biology of Anagrus atomus (L.): an egg par- asite of the leaf-hopper Erythroneura pallidifrons Edwards. Parasitology 26:57-63.

MATTEUCIG G., VIGGIANI G., 2008 - Fenologia e ospiti di Anagrus gruppo atomus (Linnaeus) (Hymenoptera: Mymaridae) in Campania. Boll. Lab. Ent. Agr. Filippo Silvestri 62: 45-50.

MONTI M.M., NAPPO A.G., MATTEUCIG G., VIGGIANI G., 2009 - Uso di tecniche molecolari per la caratterizzazione di Anagrus gruppo atomus Linnaeus (Hymenoptera: Mymaridae). - XXII Congr. Naz. Ital. Entomologia, Ancona, Italy, 15-18 giugno 2009: 330.

NOYES J.S., 2013 - Universal chalcidoidea database. Available from: www.nhm.ac.uk/entomology/chalcidoids/index.html.

NUGNES F., 2011 - Caratterizzazione morfo-bio-molecolare di Anagrus Haliday (Hymenoptera: Mymaridae) parassitoidi di uova di cicaline. Doctoral Dissertation, Università degli Studi di Napoli Federico II, Italy.

NUGNES F., VIGGIANI G., GARONNA A.P., 2011 - Dati preliminari sulla biologia di Anagrus ustulatus (Hymenoptera, Mymaridae), ooparassitoide di Lindbergina aurovittata (Hemiptera, Cicadellidae) su leccio. - Atti XXIII Congr. Naz. Ital. Entomologia, Genova, Italy, 13-16 giugno 2011: 354.

SOYKA W., 1955 - Überblick über das genus Anagrus Haliday (Alaptidae, Mymaridae, Chalcidoidea, Hymenoptera). Entomologisches Nachrichtenblatt 7: 23-26.

TSUKADA M., 1999 - Interpopulation variation of hibernal-aestival-diapause in the egg parasitoid wasp Anagrus takeyanus: adaptation to seasonal host-plant alternation of the tingid host, Stephanitis takeyai. - Entomol. Exp. Appl. 92: 37-43.

VELOCCI E., VIGGIANI G., 2008 - Osservazioni biologiche su Ficocyba ficaria (Horvath) ed i suoi ooparassitoidi nel Centro-Sud Italia. Boll. Lab. Ent. Agr. Filippo Silvestri 62: 57-62.

VIDANO C., BOSCO D., ARZONE A., 1990 - Dioecia obbligata in Lindbergina (Homoptera: Auchenorrhyncha Cicadellidae). - Redia 78: 293-306.

VIGGIANI G., 1970 - Sul valore tassinomico dell'organo copulatore nei Mimaridi del genere Anagrus Hal. Ricerche sugli Hymenoptera Chalcidoidea. XXIV. - Boll. Lab. Ent. Agr. Filippo Silvestri 28: 10-18.

VIGGIANI G., 1991 - Notizie sulla biologia e i nemici naturali di alcuni Omotteri del Leccio (Quercus ilex L.). - Atti del Convegno Problematiche fitopatologiche del genere Quercus in Italia (Firenze, Italy, 19-20 novembre 1990): 170-176.

VIGGIANI G., 2009 - Dati preliminari sugli ooparassitoidi delle cicaline del castagno. - Proc. XXII Cong. Naz. Ital. Entomologia, Ancona, Italy, 15-18 giugno 2009: 353 .

VIGGIANI G., JESU R., 2005 - Dati preliminari su popolazioni di Anagrus Haliday (Hymenoptera: Mymaridae) ottenute da uova di cicaline del rovo in Basilicata e Campania. - XX Congr. Naz. Ital. Entomologia, Perugia-Assisi, Italy, 13-18 giugno 2005: 61.

VIGGIANI G., JESU R., SASSO R., 2004a - Cicaline della vite e loro ooparassitoidi nel Sud Italia. - Boll. Lab. Ent. Agr. Filippo Silvestri 59: 3-31.

VIGGIANI G., SASSO R., BERNARDO U., 2003 - Notizie preliminari sullo svernamento di Anagrus ustulatus Haliday (Hymenoptera: Mymaridae), ooparassitoide di cicaline (Homoptera: Cicadellidae) nel Sud Italia. - Boll. Lab. Ent. Agr. Filippo Silvestri 58: 127-136.

VIGGIANI G., SASSO R., DI LUCA A., 2004b - Notizie preliminari sulle cicaline del rovo (Homoptera: Cicadellidae: Typhlocybinae) e sui loro ooparassitoidi nell'Italia Meridionale. - Boll. Lab. Ent. Agr. Filippo Silvestri 59: 33-47. 